\title{
THE EFFECT OF SOME MERCAPTANES UPON A MACRO- CRYOGELGLOBULIN; MODIFICATIONS INDUCED BY CYSTEAMINE, PENICILLAMINE AND PENICILLIN *
}

\author{
By STEPHAN E. RITZMANN, SOLON L. COLEMAN AND WILLIAM C. LEVIN
} (From the Department of Medicine and the Hematology Research Laboratory, University of
Texas Medical Branch, Galveston, Texas)

(Submitted for publication August 24, 1959; accepted April 29, 1960)

Although macroglobulinemia of Waldenström is a rare disorder, the physicochemical modification of macroglobulins therein has broad implications, since similar large proteins may be involved in the pathogenesis of symptoms associated with a variety of relatively common diseases; i.e., $\mathrm{Rh}$ isosensitization, hemolysis due to cold agglutinins, and so on. Also, a number of normally occurring proteins (properdin, isohemagglutinins, and others) are macroglobulins.

In macroglobulinemia of Waldenström the pathological proteins are responsible for the increased serum viscosity which is usually present (1). In certain instances the macroglobulins also possess the properties of cryoglobulins or cryogelglobulins, i.e., they precipitate or gel at temperatures lower than $37^{\circ} \mathrm{C}(2)$. These abnormal proteins (paraproteins) may be responsible for the production of Raynaud's phenomenon, ulcerations or gangrene. High environmental temperature may be somewhat helpful in preventing the damaging effects of cryo or cryogelglobulins. Plasmapheresis and exchange transfusions have not been found to be satisfactory in the elimination of the paraproteins over long periods of time $(3,4)$. Therefore, another avenue of investigation into phenomena related to these substances has been explored.

Deutsch and Morton (5) and Glenchur, Zinneman and Briggs (6) have demonstrated that mercaptanes will depolymerize macroglobulins. The addition of $0.1 \mathrm{M}$ cysteine at $\mathrm{pH} 7.4$ to a macroglobulin with $18 \mathrm{~S}, 25 \mathrm{~S}$ and $32 \mathrm{~S}$ components produced conversion to a single $6 \mathrm{~S}$ component. Following removal of cysteine by dialysis, there was reaggregation of the proteins with the forma-

* Aided in part by United States Public Health Grant CY-3096(C1) and American Cancer Society Grant T-168. Presented in part at the 32nd Annual Meeting of the Central Society for Clinical Research, Chicago, November 6, 1959. tion of two different types, one of $13 \mathrm{~S}$ and the other of $18 \mathrm{~S}$ (5). Heimer and Federico (7) have conclusively demonstrated that the macroglobulins representing the rheumatoid arthritis factor (19 and 22S components) can be depolymerized to a $7 \mathrm{~S}$ unit with cysteine. This reduction was associated with loss of its hemagglutination properties. Despite subsequent reaggregation, hemagglutination could not be demonstrated. Isliker (8) treated the physiological 19S $\alpha$-2-macroglobulin with cysteamine; thereafter, the ultracentrifugal pattern revealed a $6 \mathrm{~S}$ component. Depolymerization was also indicated by an immediate sharp drop (more than 50 per cent) of the original relative viscosity. In contrast to the effect upon macroglobulins, similar treatment of normal $7 \mathrm{~S}$ $\gamma$-globulins did not produce any change of the ultracentrifugal or viscosity patterns. It has been shown that cysteamine can convert properdin from a 23 to $25 \mathrm{~S}$ component to a $6 \mathrm{~S}$ fraction (8).

Methods which might induce depolymerization or abolish cryogel properties of a paraprotein associated with macroglobulinemia of Waldenström were investigated.

\section{MATERIALS AND METHODS}

The experimental material for this study was provided by a patient with macroglobulinemia of Waldenström proven by bone marrow examination, serum viscosity, and immunological and ultracentrifugation studies. The serum exhibited the properties of a cryogelglobulin between $13^{\circ}$ and $20^{\circ} \mathrm{C}$ (2). The $\mathrm{S}_{20}$ value of this protein was $19 \mathrm{~S}$ and the macroglobulin fraction comprised 38 per cent of the total serum proteins; total $\gamma$-globulin content of the serum was $7.6 \mathrm{~g}$ per $100 \mathrm{ml}$. Electrophoretically, the macroglobulin was a homogeneous $\gamma$-globulin of the intermediate type. The intrinsic viscosity [specific viscosity ${ }^{1}$ ( $\eta$ rel. -1$)$ divided by the concentration of serum protein in grams per $100 \mathrm{ml}$, at infinite dilution] of this macrocryogelglobulin was ap-

1 Relative viscosity, $\eta$ rel. 
proximately 0.125 . The axial ratio of the 95 per cent purified macroglobulin was approximately 11.5 (dehydrated) and 8.5 (hydrated). The Sia (euglobulin) test was strongly positive $[3+(2)]$.

Freshly drawn heparinized whole blood and fresh serum as well as aged serum (stored at $-20^{\circ} \mathrm{C}$ for 7 days) were used in these studies. In addition to the whole blood and serum from the patient with macroglobulinemia, heparinized whole blood samples from 7 patients with multiple myeloma and from 4 normal persons were examined.

Chemical substances used were DL-penicillamine (DLdimethylcysteine), ${ }^{2}$ cysteamine ( $\beta$-mercaptoethylamine), ${ }^{3}$ penicillin $G$ potassium (Squibb) and Benemid (Merck).

Antiserum against the patient's serum that was rich in macrocryogelglobulin ( $\mathrm{aB}$ ) was prepared by injecting $1 \mathrm{ml}$ of fresh macrocryogelglobulin serum into the marginal ear veins of a $2 \mathrm{~kg}$ rabbit every other day during a 10 day period. After 10 additional days, the rabbit was exsanguinated under sterile conditions by percutaneous cardiac puncture. The serum $(\mathrm{aB})$ was stored at $+4^{\circ} \mathrm{C}$.

\section{Studies of the effects of DL-penicillamine upon serum viscosity, gel formation, Sia test, formol gel test and serum protein content}

a. DL-Penicillamine ( $10 \mathrm{mg}$ in $0.2 \mathrm{ml}$ of 0.9 per cent sodium chloride solution) was added to $2 \mathrm{ml}$ of aged macroglobulin serum. This was incubated at $37^{\circ} \mathrm{C}$ for 15 minutes. Determination of the serum viscosity was performed at $20^{\circ} \mathrm{C}$ using an Ostwald viscosimeter of 2 $\mathrm{ml}$ volume. The relative viscosity was calculated by dividing the flow time of serum in seconds by the flow time of distilled water in seconds. Paper electrophoretic examination of the serum samples was carried out (Spinco Durrum, model R, Series C). Measurements of $\eta$ rel. and electrophoretic examinations as well as determination of the total serum proteins were made immediately before and after and 24 hours (kept at $+4^{\circ}$ C) following incubation.

b. DL-Penicillamine was administered orally (250 $\mathrm{mg}$ every 6 hours in capsules) for 19 days. Serial determinations of serum viscosity $\left(20^{\circ} \mathrm{C}\right)$ were carried out and the concentrations of the total serum proteins and globulin fractions were determined.

The serum samples were also tested for gel formation (at $4^{\circ}, 13^{\circ}$ and $20^{\circ} \mathrm{C}$ ). The Sia test and formol gel test were performed. The Sia test was performed and graded as follows (2). One drop $(0.1 \mathrm{ml})$ of serum was added to $10 \mathrm{ml}$ of electrolyte-free water using a Pasteur pipet (rinsed in electrolyte-free water). The formation of slight turbidity within 10 seconds was graded $1+$. Moderate turbidity and heavy (milky) turbidity were graded $2+$ and $3+$, respectively. Readings were performed within 10 seconds. The technique used for the formol gel test was as follows. To $0.5 \mathrm{ml}$ of serum 1 drop of 40 per cent formalin was added using a Pas-

2 Aldrich Chemical Co., Milwaukee, Wis.

${ }^{3}$ K. \& K. Laboratories, Jamaica, N. Y. teur pipet. Gel formation within 2 minutes was considered to be a positive formol gel test.

2. Studies of the effect of penicillin on viscosity, gel formation, Sia test, formol gel test, thermosedimentation rate and protein content of serum

a. To $2 \mathrm{ml}$ of freshly drawn serum from the patient with macroglobulinemia, $0.2 \mathrm{ml}$ of 0.9 per cent sodium chloride solution was added. This sample served as a control. To a second sample of macroglobulin serum, $20,000 \mathrm{U}$ of penicillin $\mathrm{G}$ potassium (Squibb) dissolved in $0.2 \mathrm{ml}$ of 0.9 per cent sodium chloride solution, was added. The serum samples were incubated at $37^{\circ} \mathrm{C}$ for 30 minutes. This procedure was also applied to aged serum. Immediately before and after incubation with penicillin $G$, the sera were tested for gel formation at $4^{\circ}$, $13^{\circ}$ and $20^{\circ} \mathrm{C}$; the viscosity was determined at $20^{\circ} \mathrm{C}$; the Sia test and formol gel test were performed.

$b$. Ten million $\mathrm{U}$ of penicillin $\mathrm{G}$ potassium in $250 \mathrm{ml}$ of 5 per cent glucose in water was infused intravenously within 1 hour. Viscosity of the serum was determined immediately before and after the injection and at 30 and 90 minutes thereafter. The sedimentation rates were determined at $37^{\circ} \mathrm{C}$ immediately before and after penicillin administration. Determination of total serum proteins and paper electrophoretic examination were carried out on serum samples removed immediately before and after penicillin infusion.

$c$. The same procedure was repeated with penicillin $G$ potassium dissolved in only $100 \mathrm{ml}$ of 5 per cent glucose in water.

$d$. The procedures were identical with those under $2 b$ except for the additional administration of Benemid in a dose of $250 \mathrm{mg}$ every 6 hours, begun 12 hours prior to the infusion of penicillin and continued to the end of the tenth day. The serum viscosity was measured immediately before and after the administration of penicillin and at time intervals of $1,2,24,48$ and 72 hours. The thermosedimentation rates were obtained by determining the sedimentation rates of heparinized blood samples simultaneously at $4,13,25$ and $37^{\circ} \mathrm{C}$ (Wintrobe).

\section{Studies of the effect of cysteamine upon the viscosity, gel formation and Sia test}

a. Two-tenths $\mathrm{ml}$ of freshly prepared cysteamine solutions of varying concentrations (1.0, 0.1 and 0.01 per cent) was added to $2 \mathrm{ml}$ of aged serum. To a fourth serum sample which served as a control, $0.2 \mathrm{ml}$ of 0.9 per cent sodium chloride solution was added. All samples were incubated at $20^{\circ} \mathrm{C}$ for 15 minutes; the $\eta$ rel., gel formation and Sia test were determined immediately before and after incubation and 24 hours later (serum was stored at $4^{\circ} \mathrm{C}$ ).

4. Studies of the effect of DL-penicillamine, penicillin $G$ potassium and cysteamine upon the immunophoretic properties of the macrocryogelglobulin

The Ouchterlony agar diffusion technique (9) was employed to study the influence of the DL-penicillamine, peni- 


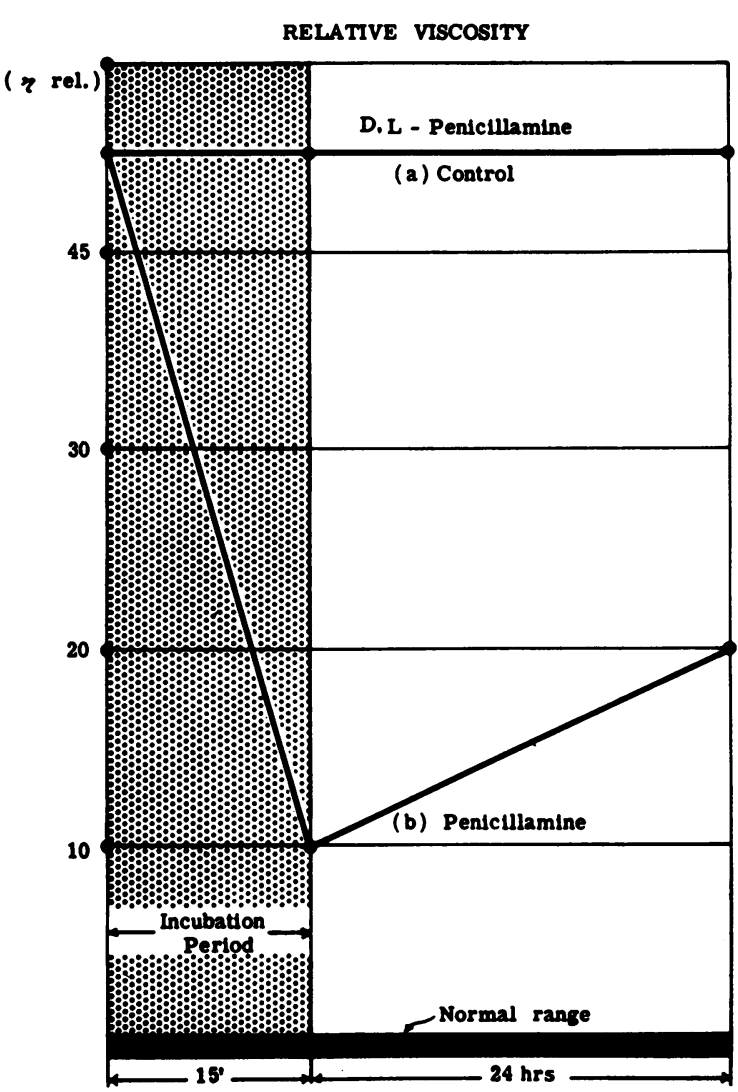

Fig. 1. Influence of IN VITRO AdDition OF DL-PENICILlamine (10 MG DISSOLVEd IN 0.2 ML OF 0.9 PER CENT NACl SOlUtion) UPON RElative Viscosity OF AGED MACROCRYOGEL SERUM (2 ML; SEE TEXT).

cillin $\mathrm{G}$ potassium and cysteamine upon the macrocryogelglobulin. In Petri dishes containing $2 \mathrm{~mm}$ thick layers of 1.5 per cent purified agar gel (Difco-Nobel agar) the precipitin reactions were observed between a rabbit antimacrocryogelglobulin serum $(\mathrm{aB})$, the macrocryogelglobulin serum (B), and an anti- $\gamma$-globulin serum ( $\mathrm{aG})$.

$a$. The patient's serum served as a control.

$b$. In a second series, DL-penicillamine was added to the agar at $40^{\circ} \mathrm{C}$ (the final concentration of penicillamine was 1 per cent) and rabbit antimacrocryogelglobulin serum $(0.6 \mathrm{ml}$ per well) was allowed to react with the macrocryogelglobulin serum $(0.4 \mathrm{ml}$ per well $)$. Readings were made after 24 hours.

c. In a third series penicillin $G$ potassium was incorporated into the agar gel. The final concentration of penicillin was 1 per cent.

$d$. In a fourth group, cysteamine was added to the agar gel (final concentration of cysteamine was 1 per cent) and rabbit antihuman macrocryogel serum was allowed to react with macrocryogelglobulin. In order to prevent dissociation of the mercaptane cysteamine, the Petri dishes were kept in an atmosphere of pure nitrogen.

To assure comparable results, each group of in vivo studies was performed only after viscosity, sedimenta-

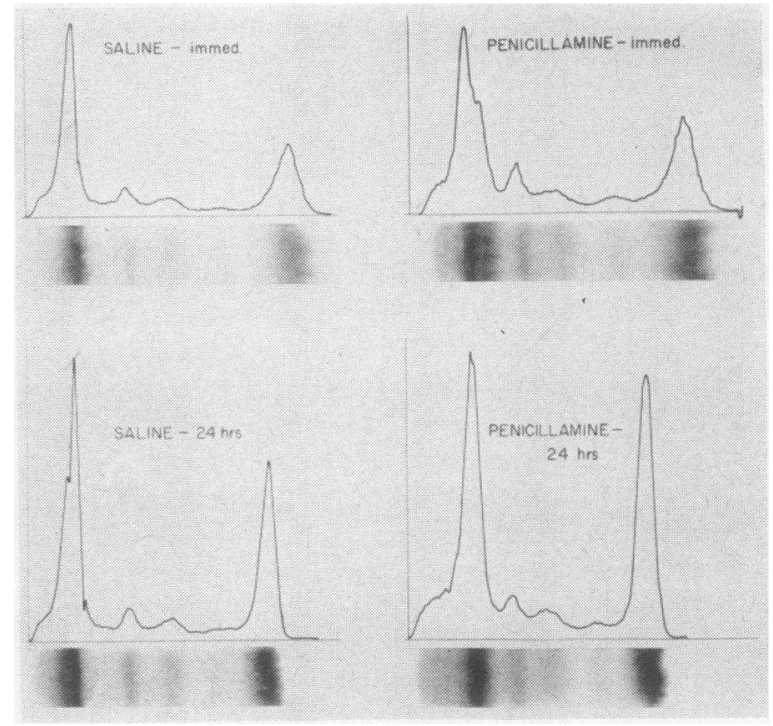

Fig. 2. Electroserogram; control Serum AND PENiCILLAMINE-TREATED SERLM IMMEDIATELY BEFORE AND AFTER INCUBATION AS WELl AS 24 hOURS LATER (SEe TEXT).

tion rate, Sia test and gel formation had returned to pretreatment levels.

\section{RESULTS}

\section{DL-Penicillamine}

$a$. The addition of DL-penicillamine to macroglobulin serum resulted in a decrease of the $\eta$ rel. from 47.4 to 10.2 immediately following incuba-

TABLE I

Effect of addition of DL-penicillamine to macroglobulin serum upon total serum proteins and electrophoretic partitions.

\begin{tabular}{|c|c|c|c|c|c|c|}
\hline & \multirow[b]{2}{*}{ T.S.P.* } & \multirow[b]{2}{*}{ Albumin } & \multicolumn{4}{|c|}{ Globulins } \\
\hline & & & $\alpha_{1}$ & $\alpha_{2}$ & $\beta$ & $\gamma$ \\
\hline 1. Control samples & $g \%$ & $\%$ & \multicolumn{4}{|c|}{$\%$} \\
\hline $\begin{array}{c}\text { Immed. before } \\
\text { incubation }\end{array}$ & 8.7 & 28.5 & 6.5 & 10.1 & 10.8 & 44.1 \\
\hline $\begin{array}{c}\text { Immed. after } \\
\text { incubation }\end{array}$ & 9.5 & 29.9 & 5.2 & 8.6 & 9.6 & 47.7 \\
\hline $\begin{array}{l}24 \text { Hrs after } \\
\text { incubation }\end{array}$ & 9.2 & 28.6 & 5.5 & 8.6 & 9.0 & 48.3 \\
\hline \multicolumn{7}{|l|}{ 2. Test samples } \\
\hline $\begin{array}{l}\text { Immed. before } \\
\text { incubation }\end{array}$ & 9.5 & 29.4 & 8.1 & 10.1 & 9.7 & 42.7 \\
\hline $\begin{array}{l}\text { Immed. after } \\
\text { incubation }\end{array}$ & 9.6 & 33.6 & 4.1 & 7.9 & 6.7 & 47.7 \\
\hline $\begin{array}{l}24 \text { Hrs after } \\
\text { incubation }\end{array}$ & 9.2 & 30.3 & 5.6 & 8.2 & 8.4 & 47.5 \\
\hline
\end{tabular}

* Total serum proteins. 


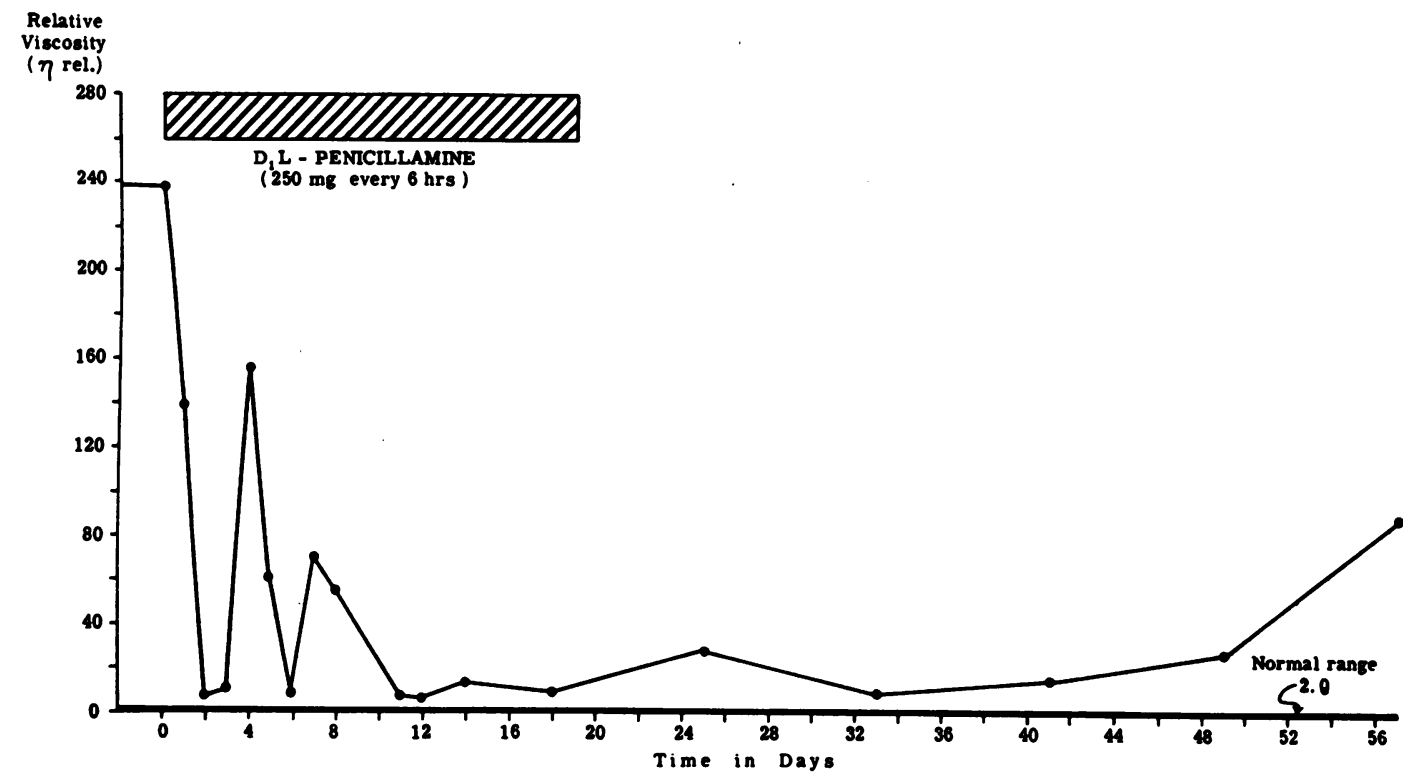

Fig. 3. INFLUENCE OF ORALly ADMinistered DL-PENiCillamine (250 MG 4 times DAILy) UPON RELATIVE VISCOSITY OF SERUM (SEE TEXT).

tion and 20.7 after 24 hours (Figure 1). Penicillamine-treated serum revealed splitting of the homogeneous main $\gamma$-globulin fraction when electroserogram was obtained immediately after incubation. Twenty-four hours later (upon standing at $25^{\circ} \mathrm{C}$ ) again a homogeneous $\gamma$-globulin fraction was seen. The control sample (saline) did

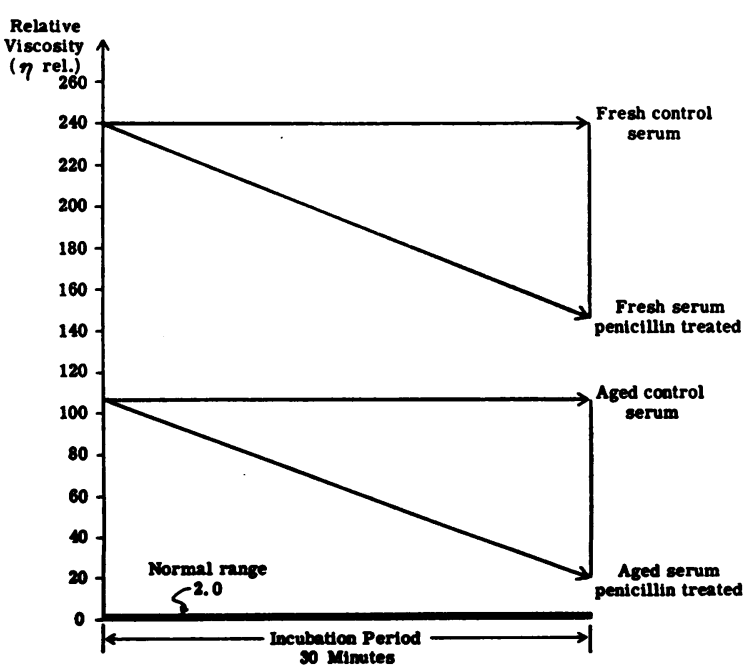

Fig. 4. INFLUENCE OF THE IN VITRO ADDITION OF PENICILLIN G POTASSIUM UPON RELATIVE VISCOSITY OF FRESH AND AGED SERUM. Two-tenths $\mathrm{ml}$ of 0.9 per cent $\mathrm{NaCl}$ solution containing $20,000 \mathrm{U}$ of penicillin $\mathrm{G}$ potassium was added to $2 \mathrm{ml}$ of serum; sera were incubated at $37^{\circ} \mathrm{C}$ for 30 minutes. not reveal these changes (Figure 2). The absolute values for the total serum proteins and the relative values for the albumin and globulin fractions are shown in Table I.

$b$. Oral administration of DL-penicillamine provoked a successive decrease of the $\eta$ rel. from 239 to 6.9 (97 per cent) within two days (Figure 3). Except for transient increases of $\eta$ rel. on Days 4 and 7, the viscosity remained at levels close to the normal range (2). Despite the discontinuance of penicillamine on Day 19, no substantial increase of viscosity appeared within the following 30 days. The absolute values of total serum proteins and relative values of the $\gamma$-globulin fractions (in parentheses) were : $9.4 \mathrm{~g}$ per $100 \mathrm{ml}$ (52.2 per cent) one day prior to the beginning of penicillamine treatment; during the treatment and posttreatment periods the following values were obtained : first day, $9.5 \mathrm{~g}$ per $100 \mathrm{ml}$ (46.5 per cent) ; sixth day, 9.6 (43.4); thirty-fifth day, 8.8 (37.9); fifty-third day 9.1 (40.7) and seventy-fifth day, 9.2 (44.4). The main $\gamma$-globulin fraction (homogeneous macroglobulin fraction) was "split" on the sixth day of the treatment period. Gel formation of the serum was abolished and the Sia test became negative on the second day of treatment. There was no change in the formol gel test throughout the test period. No major increase of 
the $\eta$ rel. was noted through the fifty-seventh day of observation.

\section{Penicillin $G$}

a. Following in vitro incubation of the serum with $20,000 \mathrm{U}$ of penicillin $\mathrm{G}$ potassium, a significant decrease of relative viscosity was observed. In treated fresh serum, the $\eta$ rel. decreased from 240 to 148 ( 38 per cent) ; in treated aged serum, the relative viscosity decreased from 107 to 20.2 (81 per cent, Figure 4 ). Gel formation occurred at temperatures between $13^{\circ}$ and $20^{\circ} \mathrm{C}$ before incubation in both fresh and aged sera, but following in vitro incubation with penicillin it did not appear at $4^{\circ}, 13^{\circ}$ or $20^{\circ} \mathrm{C}$. The Sia test was strongly positive $(3+)$ in both serum samples before incubation, but was only slightly positive $(1+)$ following incubation with penicillin. The formol gel test remained positive.

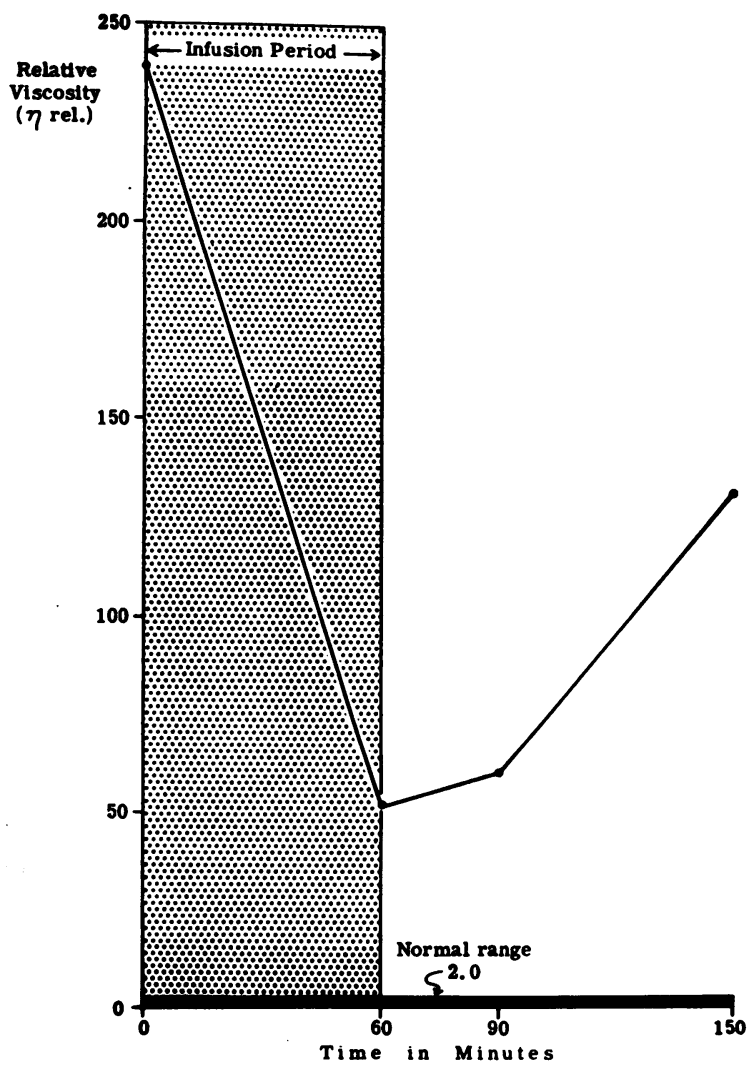

Fig. 5. INFLUENCE OF THE INTRAVENOUS ADMINISTRATION OF PENICILLIN G POTASSIUM UPON RELATIVE VISCOSITY of SERUM. Ten million $U$ of penicillin $G$ diluted in $250 \mathrm{ml}$ of 5 per cent glucose in water was given intravenously within 60 minutes.

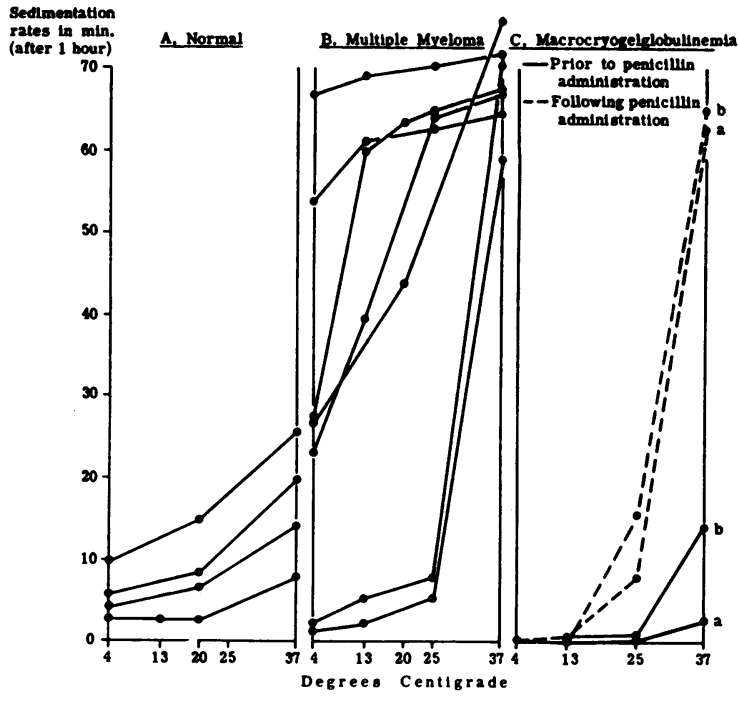

Fig. 6. Thermosedimentation Rates. At $4^{\circ}, 13^{\circ}$, $20^{\circ}, 25^{\circ}$, and $37^{\circ} \mathrm{C}$ in: $\mathrm{A}$, normal individuals [4]; $\mathrm{B}$, multiple myeloma [7]; C, macrocryogelglobulinemia ( - prior to penicillin administration, - - - following penicillin administration).

$b$. The intravenous infusion of 10 million $U$ of penicillin $G$ potassium was followed by an immediate sharp drop of the relative viscosity of the serum from 243 to 54.8 ( 77 per cent, Figure 5). Ninety minutes following the completion of the infusion there was an increase of viscosity to 130 .

The sedimentation rate prior to the penicillin administration was quite low ( $3 \mathrm{~mm}$ after 1 hour at $37^{\circ} \mathrm{C}$ ) ; whereas after penicillin infusion the

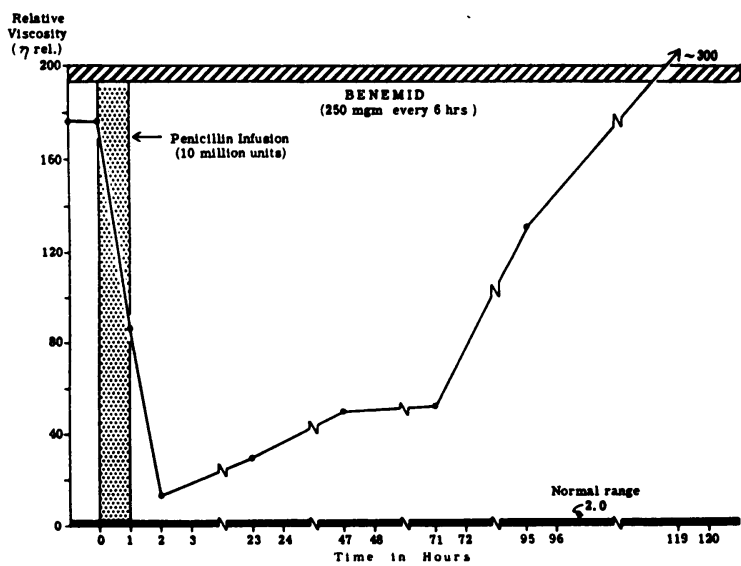

Fig. 7. Relative viscosity of SERum BEFore AND AFTER TIIE INTRAVENOUS ADMINISTRATION OF 10 MILLION U of PENicillin G POTASSIUM. In $250 \mathrm{ml}$ of 5 per cent glucose in water combined with Benemid (250 mg every 6 hours, orally). 


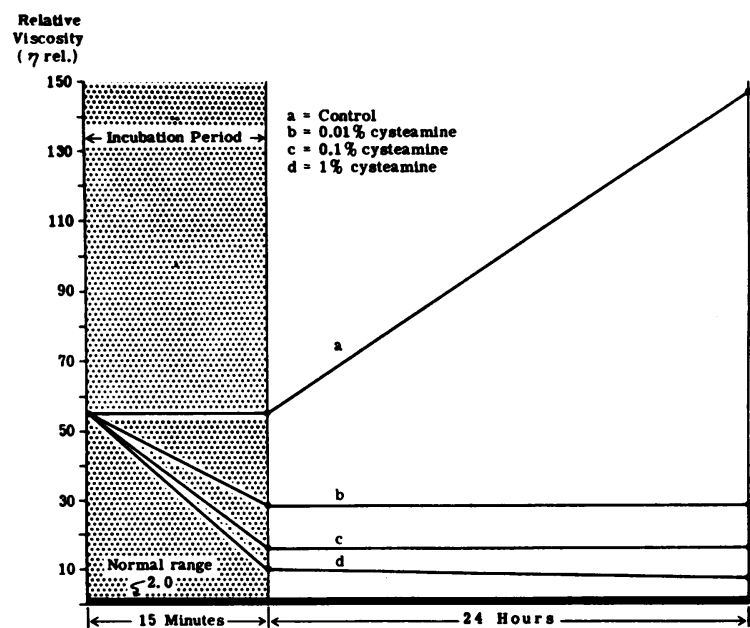

Fig. 8. INFLUENCE OF VARYing CONCENTRATIONS OF CYSTEAMINE UPON RELATIVE VISCOSITY OF AGED SERUM IN VITRO IMMEDIATELY AND 24 HOURS AFTER INCUBATION (SEE TEXT).

sedimentation rate increased to $64 \mathrm{~mm}$ after 1 hour at $37^{\circ} \mathrm{C}$ (Figure 6C, a).

c. The infusion of 10 million $\mathrm{U}$ of penicillin $\mathrm{G}$ dissolved in $100 \mathrm{ml}$ of 5 per cent glucose in water produced a decrease of serum viscosity almost identical with that seen following the infusion of penicillin in $250 \mathrm{ml}$ of 5 per cent glucose in water $(2 b)$. The sedimentation rate $\left(37^{\circ} \mathrm{C}\right)$ became rapid after penicillin infusion (from 17 to $67 \mathrm{~mm}$ after 1 hour, Figure 6C, b).

$d$. A third infusion of 10 million $U$ of penicillin $G$ potassium was combined with the administration of Benemid. Again, the drop in relative viscosity was striking (from 175.5 to 85.9 ), but no rebound phenomenon occurred. Indeed, the viscosity decreased further to 14.0 during the next hour with a total reduction of 92 per cent in relative viscosity at the end of 2 hours. Follow-up studies revealed a slight increase of viscosity during the next three days; after five days the original viscosity had been exceeded (Figure 7 ).

The pattern of the thermosedimentation rate resembled that seen in the preceding experiment $\left(0 \mathrm{~mm}\right.$ at $4^{\circ}, 0 \mathrm{~mm}$ at $13^{\circ}, 0 \mathrm{~mm}$ at $25^{\circ}$, and $2 \mathrm{~mm}$ at $37^{\circ} \mathrm{C}$ before penicillin and $0 \mathrm{~mm}$ at $4^{\circ}, 1 \mathrm{~mm}$ at $13^{\circ}, 3 \mathrm{~mm}$ at $25^{\circ}$, and $62 \mathrm{~mm}$ at $37^{\circ} \mathrm{C}, 1$ hour after penicillin administration).

\section{Cysteamine}

$a$. The relative viscosity of the aged serum before incubation with cysteamine was 56 . Imme- diately following incubation the following values were obtained: control (a) 56 ; sample (b) (0.01 per cent cysteamine) 29; sample (c) (0.1 per cent cysteamine) 16 ; sample (d) (1.0 per cent cysteamine) 11 . After 24 hours' incubation the values were as follows: control (a) 146 ; sample (b) 28.2; sample (c) 16; sample (d) 8.5 (Figure 8 ). Gel formation was abolished between $4^{\circ}$ and $20^{\circ} \mathrm{C}$ and the Sia test became negative in all three treated serum samples.

$b$. Essentially the same pattern was obtained in fresh serum (Figure 9).

4. The effect of DL-penicillamine, penicillin $G$ potassium and cysteamine upon immunophoretic properties

\section{Ouchterlony plates}

a. The control plates revealed a $\gamma$-globulin line between the antigen (B) and the antibody wells $(\mathrm{aG}$ and $\mathrm{aB}$ ) and a macrocryogelglobulin precipi-

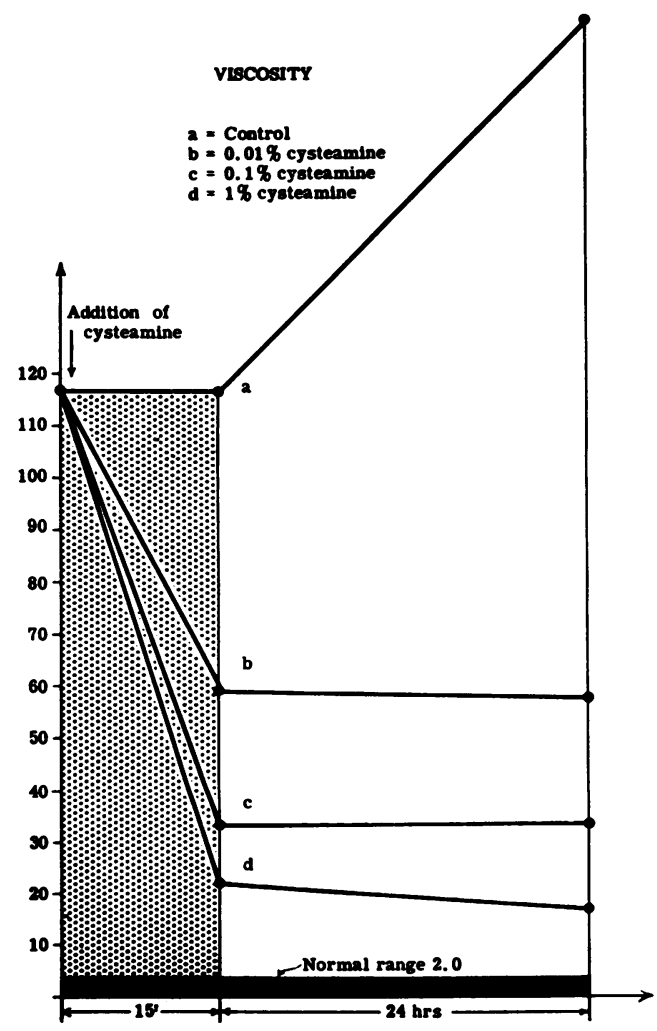

Fig. 9. Influence of VARying concentaAtions of CYSTEAMINE UPON RELATIVE VISCOSITY OF FRESH SERUM (SEE TEXT). 

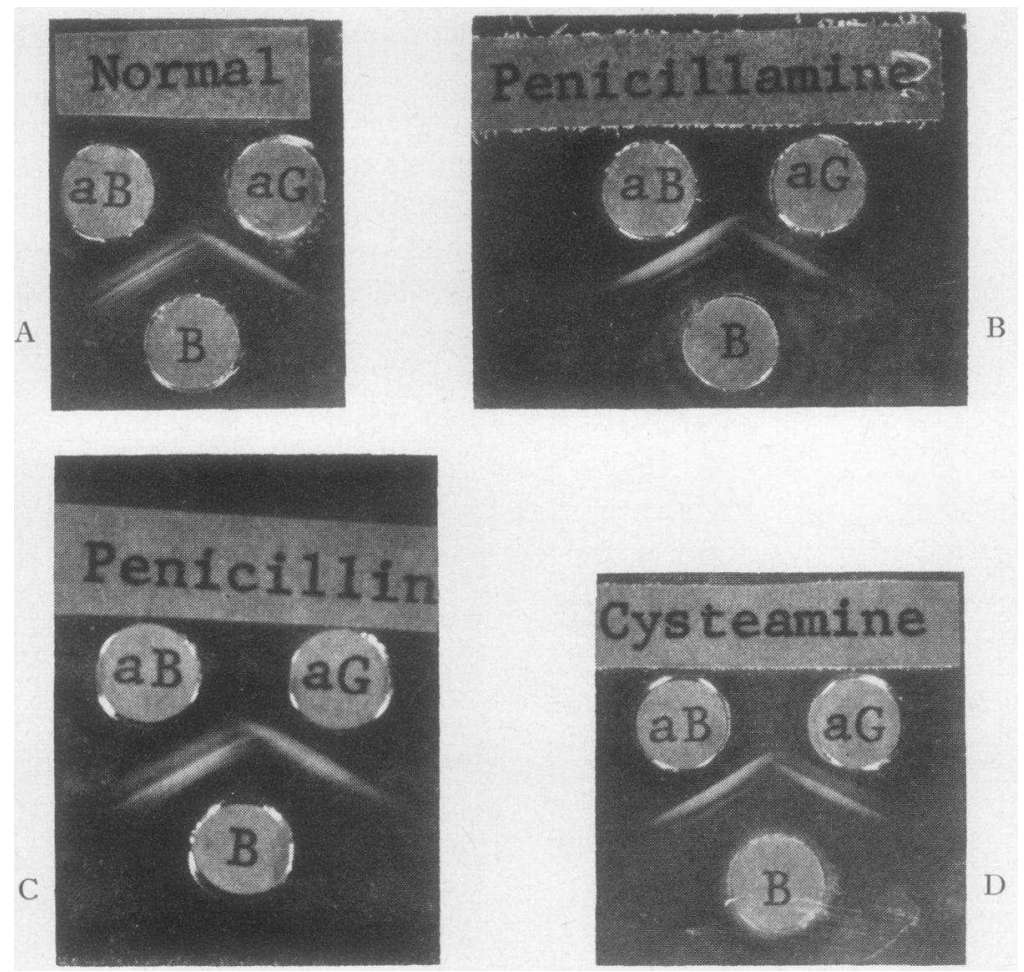

Fig. 10. Ouch terlony agar gel diffusion tests. The samples were allowed to diffuse from their respective wells. At the site of confluence precipitin lines were formed [aB: anti-human macrocryogelglobulin-serum; B: macrocryogelglobulin-serum; aG : anti- $\gamma$-globulin-serum (Behring) ].

A. Control. The precipitin line close to the antibody well $(\mathrm{aB})$ represents the $\gamma$-globulin line; the well-outlined line in the middle between the $\mathrm{aB}$ and $\mathrm{B}$ wells is the macroglobulin precipitin line; the precipitin line between $B$ and aG represents the $\gamma$-globulin line.

B. Following the addition of DL-penicillamine to the agar gel, the precipitin lines of the macroglobulin have joined those of $\gamma$-globulin, indicating a change in diffusion rate and immunological affinity to $\gamma$-globulin.

C. The addition of penicillin to the agar gel reveals no changes as compared with the control plates (A).

D. Cysteamine has resulted in changes of mobility of the macrocryogelglobulin which are comparable with those seen after the addition of DL-penicillamine.

tin line between the antibody $(\mathrm{aB})$ and antigen wells (Figure 10A).

$b$. The addition of DL-penicillamine resulted in the disappearance of the macroglobulin precipitin line and an increase of the $\gamma$-globulin line which shares partial antigenicity with the gamma line between $B$ and aG (Figure 10B).

c. Penicillin $\mathrm{G}$ potassium did not evoke any obvious changes of the precipitin pattern (Figure 10C).

$d$. The addition of cysteamine to the agar gel resulted in disappearance of the macroglobulin precipitin lines, and an increase of the $\gamma$-globulin precipitin lines was noted (Figure 10D).

\section{DISCUSSION}

DL-Penicillamine is used as a chelating agent in heavy metal poisoning (10) and in Wilson's disease (11-13). Toxic side effects, such as inhibition of growth in animals (14), interference with vitamin $B_{6}$ utilization $(12,14-16)$ and the activity of some hepatic transaminases $(16,17)$ as well as dermatological manifestations (18) have been produced by the $\mathrm{L}$-form of penicillamine. 
D-Penicillamine appears to be nontoxic (14). The high price of this compound, however, limits its liberal clinical use. Penicillin is partly metabolized into D-penicillamine $(12,19-21)$. The above observations indicate that both penicillin (or a breakdown product of penicillin) and DL-penicillamine produce pronounced changes in the physical characteristics of the serum both in vivo and in vitro. Also, after penicillamine and penicillin therapy there was marked clinical improvement, which was reflected by disappearance of cold intolerance, cessation of hemorrhagic diathesis with normalization of clotting status, increase in appetite and weight, and generalized feeling of wellbeing.

Following depolymerization of macroglobulins with mercaptanes, there is usually a pronounced rebound of the $\eta$ rel. (Figures $1,5,7$ ). Thus, the $\eta$ rel. may even exceed the original value within one hour (8). The pronounced rebound of $\eta$ rel. following the infusion of penicillin $\mathrm{G}$ imitates this characteristic feature of depolymerization although the alterations in the physical characteristics of the serum reported herewith could theoretically be due to some molecular modification other than depolymerization. The prolonged decrease of serum viscosity and increase in thermosedimentation rate following the penicillin infusion with Benemid suggest increased retention and sustained action of either penicillin or a metabolite, such as penicillamine. The altered pattern of thermosedimentation rate following treatment with penicillin and penicillamine both in vitro and in vivo is similar to that seen in some untreated myeloma sera with $7 \mathrm{~S}$ paraproteins (Figure 6B).

The failure of the relative viscosity to return completely to normal may be due either to persistence of macroglobulins or to an increased amount of $7 \mathrm{~S}$ globulins. In the presence of macroglobulins without cryo or cryogel properties the serum viscosity is higher than normal. However, it has been conclusively shown that increased quantities of $7 \mathrm{~S} \gamma$-globulins can also produce slightly increased $\eta$ rel. This is particularly true in the presence of $7 \mathrm{~S}$ paraproteins, such as multiple myeloma protein (22). Disintegration of a pathological macroglobulin may result in the production of such a small sized paraprotein.

On theoretical grounds, removal of the macroglobulin from the blood could explain these find- ings. Unchanged total serum protein and electrophoretic results of the examined serum samples immediately before and after treatment with penicillamine in vitro and in vivo rule out this possibility. Furthermore, Isliker's findings (8) of pronounced reduction in the serum viscosity with subsequent rebound following the depolymerization of the $\alpha_{2}$-macroglobulin are similar to observations made following treatment of our serum samples with penicillamine and penicillin.

The change in the Sia test readings may be attributed to reduction in the molecular size of the macroglobulin, since the precipitation of the paraproteins appears to be independent of the cryo or cryogel properties. According to Steel (23) the Sia test can be employed in testing the stability of macroglobulins. In contrast, the abolishment of gel-forming characteristics following treatment with penicillin, penicillamine and cysteamine can be explained by inactivation of the cryogel properties of the macroglobulin without additional dissociation of the macromolecule.

Hitzig, however, has been able to demonstrate (24) a slow spontaneous dissociation of this macrocryogelglobulin of an aged serum sample. The addition of cysteamine to the serum and to the purified macrocryogelglobulin greatly accelerated this dissociative process. This finding is comparable with the results of Métais and Warter [cited by Hitzig and Isliker (25)] who found a slowly decreasing high molecular fraction from the serum of a patient with macroglobulinemia merely after dilution. Steel (23) also observed spontaneous dissociation of isolated macroglobulins at room temperature and at $37^{\circ} \mathrm{C}$. We (26) have encountered decreasing serological activity as reflection of depolymerization of macromolecular cold agglutinins during a storage period of four months at $-20^{\circ} \mathrm{C}$. Spontaneous dissociation probably accounts for the lower $\eta$ rel. of aged macroglobulin serum, as seen in samples of aged macrocryogelglobulin serum.

The profound decrease of relative viscosity following incubation of the serum with cysteamine may thus reflect dissociation of the macroglobulin (8). Reduction of viscosity, abolishment of gel formation and conversion of a strongly to a weakly positive or negative Sia test following in vitro treatment of the macroglobulin serum with penicillamine and penicillin, as well as following adminis- 
tration of these agrents to the patient, were similar quantitatively and qualitatively. Both penicillamine (26-28) in vivo, and cysteanine $(8,24,25)$ in vitro are able to depolymerize macroglobulins as demonstrated by ultracentrifugation. The marked changes of viscosity, Sia test and gel formation in the macroglobulin are certainly compatible with dissociation of the macroglobulin. The electrophoretic changes of penicillaminetreated serum favor this suggestion. The resemblance of the reaction pattern of penicillin $G$ upon the macroglobulin is suggestive of the same mechanism. The inactivity of penicillin in the agar gel diffusion test supports, however, the concept that a metabolite of penicillin (D-penicillamine?) may be responsible for the in vivo action. The conversion of penicillin into D-penicillamine appears to be dependent upon certain agents present in serum. The lack of activity of penicillin, incorporated into agar-gel, could thus be explained.

Regardless of the underlying mechanism, this biochemical approach to macroglobulinemias, particularly those with cryo or cryogel characteristics, may be of clinical value. This is supported by the marked clinical improvement of the patient under study. Description of this observation will be reported elsewhere.

\section{SUMMARY}

The effects of penicillin G potassium, DL-penicillamine and cysteamine upon a macrocryogelglobulin were investigated. Changes of serum viscosity, thermosedimentation rates, gel formation, Sia test, total serum protein, paper electrophoretic characteristics and immunophoretic properties served as indicators.

Administration of DL-penicillamine produced a marked sustained decrease of relative viscosity and an increase of sedimentation rate. DL-Penicillamine, added to macrocryogelglobulin serum in vitro resulted in marked decrease of relative viscosity, widening of macroglobulin fraction in electrophoretic pattern, and a negative Sia test and abolishment of gel formation.

Penicillin $G$ added to serum produced a marked decrease of relative viscosity, a negative Sia test and abolishment of gel formation.

Penicillin G, 10 million $U$ given intravenously, lowered the serum viscosity by 77 per cent within one hour and increased the previously low sedimentation rates sharply. Rapid rebound of viscosity occurred.

The coincident administration of Benemid with penicillin enhanced this effect and delayed rebound of viscosity considerably.

Addition of cysteamine to serum resulted in dosage-dependent decrease of relative viscosity.

Agar diffusion studies revealed the simultaneous disappearance of the macroglobulin precipitin line and a quantitative increase in the $\gamma$-globulin line with DL-penicillamine and cysteamine; no changes were produced by penicillin $\mathrm{G}$.

It is suggested that the compounds studied were responsible for abolishment of cryogel properties and probably produced dissociation of the macroglobulin. Possible clinical implications are mentioned.

\section{ACKNOWLEDGMENT}

We are grateful for the technical assistance of Mrs. M. Lawrence and Mrs. J. Witt.

\section{REFERENCES}

1. Waldenström, J. Recherches cliniques et physicochimiques sur les hyperglobulinémies. Presse méd. 1949, 57, 213.

2. Ritzmann, S. E., Thurm, R. H., Truax, W. E., and Levin, W. C. The syndrome of macroglobulinemia: Review of the literature and a report of two cases of macrocryogelglobulinemia. Arch. intern. Med. 1960, 6, pp. 161, 939.

3. Skoog, W. A., and Adams, W. S. Plasmapheresis in a case of Waldenström's macroglobulinemia. Clin. Res. 1959, 7, 96.

4. Auerswald, W., Braunsteiner, H., and Reimer, E. E. Electrophoretische Studie des Einflusses der Austauschtransfusion auf das pathologische Proteingleichgewicht bei $\gamma$-Plasmozytom. Wien. $Z$. inn. Med. 1951, 32, 97.

5. Deutsch, H. F., and Morton, J. I. Dissociation of human serum macroglobulins. Science 1957, 125, 600.

6. Glenchur, H., Zinneman, H. H., and Briggs, D. R. Macroglobulinemia: Report of two cases. Ann. intern. Med. 1958, 48, 1055.

7. Heimer, R., and Federico, O. M. Depolymerization of the $19 \mathrm{~S}$ antibodies and the $22 \mathrm{~S}$ rheumatoid factor. Clin. chim. Acta 1958, 3, 496.

8. Isliker, $\mathrm{H}$. Zur Chemie der Makroglobuline. Helv. med. Acta 1958, 25, 41.

9. Ouchterlony, Ö. In vitro method for testing the toxin-producing capacity of diphtheria bacteria. Acta path. microbiol. scand. 1948, 25, 186. 
10. Boyd, P. R., Walker, G., and Henderson, I. N. The treatment of tetraethyl lead poisoning. Lancet 1957, 1, 181.

11. Walshe, J. M. Penicillamine-A new oral therapy for Wilson's disease. Amer. J. Med. 1956, 21, 487.

12. Fister, W. P., Boulding, J. E., and Baker, R. A. The treatment of hepatolenticular degeneration with penicillamine, with report of two cases. Canad. med. Ass. J. 1958, 78, 99.

13. Osborn, S. B., and Walshe, J. M. Effects of penicillamine and dimercaprol on turnover of copper in patients with Wilson's disease. Lancet 1958, 1, 70.

14. Wilson, J. E., and DuVigneaud, V. Inhibition of the growth of the rat by L-penicillamine and its prevention by aminoethanol and related compounds. J. biol. Chem. 1950, 184, 63.

15. Kuchinskas, E. J., and DuVigneaud, V. An increased vitamin $B_{6}$ requirement in the rat on a diet containing L-penicillamine. Arch. Biochem. 1957, 66, 1.

16. Kuchinskas, E. J., Horvath, A., and DuVigneaud, V. An anti-vitamin $B_{6}$ action of L-penicillamine. Arch. Biochem. 1957, 68, 69.

17. DuVigneaud, V., Kuchinskas, E. J., and Horvath, A. L-penicillamine and rat liver transaminase activity. Arch. Biochem. 1957, 69, 130.

18. Tabachnick, M., Eisen, H. N., and Levine, B. A new mixed disulphide: Penicillamine-cysteine. $\mathrm{Na}$ ture (Lond.) 1954, 174, 701.
19. Committee on Medical Research, O.S.R.D., Washington, and the Medical Research Council, London. Chemistry of penicillin. Science 1945, 102, 627.

20. Goodman, L. S., and Gilman, A. The Pharmacological Basis of Therapeutics, 2nd ed. New York, Macmillan, 1955 , p. 1327.

21. Walshe, J. M. Disturbances of aminoacid metabolism following liver injury. A study by means of paper chromatography. Quart. J. Med. 1953, 22, 483.

22. Jahnke, K., Scholtan, W., and Heinzler, F. Die Viskosität von Seren und isolierten Serumproteinen bei Makroglobulinämien und anderen Dys- und Paraproteinämien. Helv. med. Acta 1958, 25, 2.

23. Steel, A. E. Physico-chemical studies on four macroglobulins. Clin. chim. Acta 1959, 4, 420.

24. Hitzig, W. H. Personal communication.

25. Hitzig, W. H., and Isliker, H. C. Immunological studies on dissociation of human macroglobulins in Proc. 7th Coll. on Protides of the Biological Fluids, H. Peeters, Ed. Amsterdam, Elsevier Publishing, 1960, p. 368 .

26. Ritzmann, S. E., and Levin, W. C. The effects of mercaptanes in cold agglutinin disease. J. Lab. clin. Med. Submitted for publication.

27. Bloch, H. S., Prasad, A., and Anastasi, A. Serum protein changes in Waldenström's macroglobulinemia during penicillamine administration (abstract). J. Lab. clin. Med. 1958, 52, 793.

28. Levine, M. A., Hammack, W. J., and Frommeyer, W. B. Treatment of macroglobulinemia with penicillamine. Clin. Res. 1960, 8, 54. 